\title{
New species of Thozetella and Chaetosphaeria and new records of Chaetosphaeria and Tainosphaeria from Thailand
}

\section{Perera $\mathrm{RH}^{1,2}$, Maharachchikumbura $\mathrm{SSN}^{3}$, Bhat $\mathrm{JD}^{4}$, Al-Sadi $\mathrm{AM}^{3}$, Liu $\mathrm{JK}^{1}$, Hyde $\mathrm{KD}^{2,5,6}$ and Liu $\mathrm{ZY}^{1}$}

${ }^{1}$ Guizhou Key Laboratory of Agricultural Biotechnology, Guizhou Academy of Agricultural Sciences, Xiaohe District, Guiyang City, Guizhou Province 550006, People's Republic of China

${ }^{2}$ Center of Excellence in Fungal Research, Mae Fah Luang University, Chiang Rai 57100, Thailand

${ }^{3}$ Department of Crop Sciences, College of Agricultural and Marine Sciences, Sultan Qaboos University, PO Box 34, Al Khoud 123, Oman

${ }^{4}$ Formerly at Department of Botany, Goa University, Goa 403206, India

${ }^{5}$ Key Laboratory for Plant Biodiversity and Biogeography of East Asia (KLPB), Kunming Institute of Botany, Chinese Academy of Science, Kunming 650201, Yunnan, China

${ }^{6}$ World Agroforestry Centre, East and Central Asia, 132 Lanhei Road, Kunming 650201, China

Perera RH, Maharachchikumbura SSN, Bhat JD, Al-Sadi AM, Liu JK, Hyde KD, Liu ZY. 2016 New species of Thozetella and Chaetosphaeria and new records of Chaetosphaeria and Tainosphaeria from Thailand. Mycosphere 7 (9), 1301-1321, Doi 10.5943/mycosphere/7/9/5

\begin{abstract}
We are studying seed and fruit-borne fungi in Thailand and in this paper report on species of Tainosphaeria, Thozetella and Chaetosphaeria from Fabaceae seed pods and decorticated wood, collected in Chiang Mai and Phang-nga provinces. Phylogenetic analysis of combined LSU, ITS and TUB sequence data provides evidence for new species of Thozetella and Chaetosphaeria. These new taxa are introduced and compared with closely related species in these genera. We provide a morphological and illustrated account of Chaetosphaeria panamensis isolated from Pinus twigs as a first record for Thailand.
\end{abstract}

Key words - Chaetosphaeriales - morphology - phylogeny - seed/fruit fungi - Sordariomycetes

\section{Introduction}

The hyphomycetous genus Thozetella Kuntze was introduced by Kuntze (1891) based on T. nivea (Berk.) Kuntze. The genus presently includes 19 epithets (Index Fungorum 2016) and is characterized by sporodochial or synnematous conidiomata, phialidic conidiogenesis, and aseptate conidia, with unbranched setula at each end and sterile microawns (Sutton \& Cole 1983, Paulus et al. Hyde 2004). Thozetella species have been reported from soil and decaying plant parts in terrestrial and freshwater habitats from temperate and tropical regions (Morris 1956, Agnihothrudu 1958, 1962, Waipara et al. 1996, Sivichai et al. 2002, Allegrucci et al. 2004, Delgado-Rodrígues \& Mena-Portales 
2004, Paulus et al. 2004, Pinruan et al. 2007, Jeewon et al. 2009, Barbosa et al. 2011, Silva \& Grandi 2011, 2013). It will be interesting to use molecular data to establish if the morphologically similar taxa from extreme regions are the same species.

Species of Tainosphaeria F.A. Fernández \& Huhndorf are saprobes, and generally isolated from erumpent stromata of over-matured ascomycetes. The genus, typified by $T$. crassiparies F.A. Fernández \& Huhndorf, is characterized by subglobose to ovoid ascomata, simple, septate paraphyses, cylindrical, pedicellate asci with an apical ring, and narrow-fusiform, septate, hyaline ascospores (Fernández \& Huhndorf 2005). The asexual morph is hyphomycetous, with mononematous, unbranched conidiophores, terminating in cylindrical phialides with a collarette and ellipsoidal to clavate, or falcate, hyaline conidia (Fernández \& Huhndorf 2005).

The saprobic genus, Chaetosphaeria Tul. \& C. Tul. had been placed in Lasiosphaeriaceae by Barr (1990) and is presently included in Chaetosphaeriaceae (Chaetosphaeriales) (Réblová et al. 1999, Huhndorf et al. 2004, Maharachchikumbura et al. 2015, 2016) based on molecular data. Morphological characters of the sexual morph are simple and hardly distinguishable, while the asexual morphs characters are considered as distinctive (Gams \& Holubová-Jechová 1976, Huhndorf et al. 2004). The asexual morph of Chaetosphaeria is hyphomycetous with macronematous or mononematous conidiophores, monophialidic or polyphialidic, hyaline, conidiogenous cells, with a distinct funnel-shaped collarette and hyaline to brown, aseptate to multi-septate, guttulate or eguttulate conidia, with or without appendages (Maharachchikumbura et al. 2016). Species in this genus are recorded on decayed plant material in terrestrial and freshwater habitats, worldwide (Ho et al. 2001, Huhndorf et al. 2001, Fernández \& Huhndorf 2005, Fernández et al. 2006, Atkinson et al. 2007).

We introduce three new taxa belonging in Chaetosphaeriaceae collected from Fabaceae seed pods, with support from molecular and morphological data. New record of Chaetosphaeria panamensis for Thailand is also illustrated. This is the first record of Tainosphaeria siamensis on Fabaceae seed pods.

\section{Materials and methods}

\section{Sample collection, specimen examination and isolation}

Specimens were collected from Thailand during 2014 to 2015, and macroscopic and microscopic characters were observed in the laboratory. Fungal structures were observed using a Motic dissecting microscope (SMZ 168) and a Nikon ECLIPSE 80i compound microscope. Free hand sections of fungal structures were taken wherever necessary and mounted in water and Melzer's reagent for microscopic study. Photomicrography was carried out using a Canon 450D digital camera fitted to the microscope. Measurements were made with the Tarosoft (R) Image Frame Work software. The images used for illustrating the fungi were processed with Adobe Photoshop CS5 v. 12.0 software (Adobe Systems, USA). Single ascospore/conidial colonies were established as described in Chomnunti et al. (2014). Colonies were sub-cultured on Malt Extract Agar (MEA) and incubated at room temperature at $28{ }^{\circ} \mathrm{C}$. To induce sporulation, cultures were incubated at $28{ }^{\circ} \mathrm{C}$ in the dark.

Herbarium specimens are deposited in the Mae Fah Luang University (MFLU) herbarium, Chiang Rai, Thailand. Living cultures are deposited in the Culture Collection at Mae Fah Luang University (MFLUCC). Facesoffungi and Index Fungorum numbers were registered as explained in Jayasiri et al. (2015) and Index Fungorum (2016). 
Table 1 Information on loci and PCR protocols used in the study.

\begin{tabular}{|c|c|c|}
\hline Locus & Primers (Reference) & PCR conditions \\
\hline ITS & ITS5/ITS4 (White et al. 1990) & $\begin{array}{l}{ }^{\mathrm{a}} 94^{\circ} \mathrm{C}: 30 \mathrm{~s}, 53^{\circ} \mathrm{C}: 30 \mathrm{~s}, \\
72^{\circ} \mathrm{C}: 1.30 \mathrm{~min}(37 \text { cycles })^{\mathrm{b}}\end{array}$ \\
\hline LSU & $\begin{array}{l}\text { LR5/LR0R (Vilgalys \& Hester 1990, Rehner } \\
\text { \& Samuels 1994) }\end{array}$ & $\begin{array}{l}{ }^{\mathrm{a}} 94{ }^{\circ} \mathrm{C}: 30 \mathrm{~s}, 48^{\circ} \mathrm{C}: 30 \mathrm{~s}, \\
72^{\circ} \mathrm{C}: 1.30 \min (35 \text { cycles })^{\mathrm{b}}\end{array}$ \\
\hline$T U B$ & Bt2a/Bt2b (Glass \& Donaldson 1995) & $\begin{array}{l}{ }^{\mathrm{a}} 94^{\circ} \mathrm{C}: 30 \mathrm{~s}, 58^{\circ} \mathrm{C}: 30 \mathrm{~s}, \\
72{ }^{\circ} \mathrm{C}: 1.30 \min (37 \text { cycles })^{\mathrm{b}}\end{array}$ \\
\hline
\end{tabular}

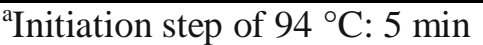

${ }^{\text {b} F i n a l ~ e l o n g a t i o n ~ s t e p ~ o f ~} 72{ }^{\circ} \mathrm{C}: 7 \mathrm{~min}$ and final hold at $4{ }^{\circ} \mathrm{C}$ applied to all PCR thermal cycles

\section{DNA isolation, amplification and analyses}

Genomic DNA was extracted from fungal colonies growing on MEA or directly from the fruiting bodies on the natural substrate, using the Ezup DNA Extraction Kit (Sangon Biotech, Shanghai, China) according to the manufacturer's protocol. Partial 28S large subunit nrDNA (LSU), the internal transcribed spacer (ITS) and partial $\beta$-tubulin (TUB) were amplified using the primer pairs and PCR protocols listed in Table 1. PCR was performed in a $25 \mu 1$ reaction volume containing, $12.5 \mu 12 \times$ PCR Master Mix (TIANGEN Co., China), $9.5 \mu 1 \mathrm{ddH}_{2} \mathrm{O}, 1 \mu \mathrm{l}$ DNA $(<1 \mu \mathrm{g})$ and $1 \mu \mathrm{l}$ of each primer $(10 \mu \mathrm{M})$. PCR products were viewed on $1 \%$ agarose gels and stained with ethidium bromide. Purification and sequencing of PCR products were done by Invitrogen Biotechnology Co. Ltd., Beijing, China. To ensure the integrity of the sequences, both directions of the PCR products were sequenced using the same primer pairs as used in PCR amplification. A consensus sequence for each gene region was assembled in ContigExpress (Vector NTI Suite 6.0).

The sequences generated in this study were supplementary with the additional sequences obtained from GenBank (Table 2) selected based on recent publications on this group (Crous et al. 2012, Maharachchikumbura et al. 2015, 2016). The sequence data were aligned online with the MAFFT v. 7 server (http://mafft.cbrc.jp/ alignment/server/) and manually adjust using MEGA6 v. 6.0 where necessary (Tamura et al. 2011). Phylogenetic analyses were based on Bayesian inference (BI) and maximum likelihood (ML) analysis. ML analyses was performed using RAxML GUI v. 1.3 (Silvestro \& Michalak 2011). The optimal ML tree search was conducted with 1000 separate runs, using the default algorithm of the program from a random starting tree for each run. The final tree was selected among suboptimal trees from each run by comparing likelihood scores with the GTRGAMMA nucleotide substitution model. Bayesian analysis was performed using MrBayes v. 3.2.0 (Huelsenbeck \& Ronquist 2001). The best-fit evolutionary models for phylogenetic analyses were selected separately for LSU, ITS and TUB gene regions using MrModeltest v. 2.2 (Nylander 2004). The GTR+I+G model was selected for each gene separately, and incorporated into the analysis. Two parallel analyses of each consisting of six Markov Chain Monte Carlo (MCMC) chains, run from random trees for 5000000 generations were sampled every 100 generations resulting in 20 000 total trees. The first 10000 trees, representing the burn in phase of the analyses were discarded from each run. The remaining trees were used to calculate posterior probabilities (PP) in the majority rule consensus tree. ML bootstrap values (>50\%) (ML) and Bayesian posterior probabilities (>90\%) (PP) are provided (Fig 1). Trees were viewed by FigTree v1.4 (http://tree.bio.ed.ac.uk/software/figtree/) and edited using Microsoft PowerPoint 2016. 
Table 2 GenBank accession numbers of the isolates used in this study

\begin{tabular}{|c|c|c|c|c|}
\hline \multirow[t]{2}{*}{ Taxon } & \multirow{2}{*}{ Collection/Isolate no. } & \multicolumn{3}{|c|}{ GenBank accession no. } \\
\hline & & LSU & ITS & TUB \\
\hline $\begin{array}{l}\text { Brunneodinemasporium } \\
\text { brasiliense }\end{array}$ & CBS 112007 & JQ889288 & JQ889272 & - \\
\hline Chaetosphaeria abietis & CBS 427.83 & - & AF178541 & - \\
\hline C. acutata & CBS 101312 & AF178553 & AF178553 & - \\
\hline C. albida & PDD 92537 & EU037898 & EU037890 & - \\
\hline C. bombycina & PDD 92538 & - & EU037892 & - \\
\hline C. caesariata & SMH 279 & AF466060 & - & AF466020 \\
\hline C. callimorpha & CBS 525.88 & AF178555 & AF178555 & - \\
\hline C. capitata & SMH 3239 & AF466061 & - & AF466021 \\
\hline C. chalaroides & SMH 2223 & AF466063 & - & AF466024 \\
\hline C. chloroconia & MR 1119 & - & AF178542 & - \\
\hline C. chlorotunicata & SMH 1565 & AF466064 & - & AF466025 \\
\hline C. ciliata & ICMP 18253 & GU180637 & - & - \\
\hline C. conirostris & SMH 2183 & AF466066 & - & AF466027 \\
\hline C. cubensis & SMH 3258 & AF466067 & - & AF466028 \\
\hline C. curvispora & ICMP 18255 & GU180636 & - & - \\
\hline C. cylindrospora & SMH 3568 & AY017373 & - & - \\
\hline C. decastyla & SMH 2629 & AF466068 & - & AF466029 \\
\hline C. dilabens & CBS 712.88 & AF178557 & AF178557 & - \\
\hline C. ellisii & SMH3860 & - & AY906944 & - \\
\hline C. fennica & CBS 101641 & AF178562 & AF178562 & - \\
\hline C. fuegiana & ICMP 15153 & EF063574 & - & - \\
\hline C. fusiformis & CBS 101429 & AF178554 & AF178554 & - \\
\hline C. garethjonesii & MFLUCC 15-1012 & KY212759 & KY212751 & KY212755 \\
\hline C. hebetiseta & SMH 2729 & AF466069 & AY906955 & AF466030 \\
\hline C. inaequalis & MR 1450 & AF178564 & AF178564 & - \\
\hline C. innumera & SMH 2748 & AY017375 & AY906956 & AF466018 \\
\hline C. jonesii & MFLUCC 15-1015 & KY212761 & KY212753 & KY212757 \\
\hline C. lapaziana & SMH 3043 & - & AY906947 & - \\
\hline C. lateriphiala & SMH 3320 & AF466072 & - & AF466033 \\
\hline C. lentomita & MR 1265 & AF178548 & AF178548 & - \\
\hline C. lignomollis & SMH 3015 & AF466073 & EU037896 & AF466034 \\
\hline C. longiseta & SMH 1725 & AF279416 & - & AF466035 \\
\hline C. luquillensis & SMH 2973 & AF466074 & - & AF466037 \\
\hline C. metallicans & PDD 92539 & EU037899 & EU037893 & - \\
\hline C. minuta & SMH3396 & AF466075 & - & AF466038 \\
\hline C. myriocarpa & MUCL 34784 & AF466076 & - & AF466039 \\
\hline C. panamensis & SMH 3596 & - & AY906948 & - \\
\hline C. panamensis & MFLUCC 15-1011 & KY212760 & KY212752 & KY212756 \\
\hline C. preussii & CBS 262.76 & AF178561 & AF178561 & - \\
\hline C. pygmaea & UPSC 2523 & AF466077 & - & AF466040 \\
\hline C. raciborski & SMH 2017 & AF466078 & AY906949 & AF466041 \\
\hline C. rivularia & CBS 127686 & KR347357 & KR347356 & - \\
\hline C. sylvatica & SMH 2893 & AF279419 & - & AF466043 \\
\hline
\end{tabular}




\begin{tabular}{|c|c|c|c|c|}
\hline \multirow[t]{2}{*}{ Taxon } & \multirow{2}{*}{ Collection/Isolate no. } & \multicolumn{3}{|c|}{ GenBank accession no. } \\
\hline & & LSU & ITS & TUB \\
\hline C. talbotii & EXP0560F & - & DQ914666 & - \\
\hline C. tropicalis & SMH 1267 & AF279418 & - & AF466044 \\
\hline C. vermicularioides & MR 1148 & AF178550 & AF178550 & - \\
\hline $\begin{array}{l}\text { Chloridium vermicularioides } \\
=\text { "Melanopsammella } \\
\text { vermicularioides" }\end{array}$ & FC404 & AF466087 & - & AF466052 \\
\hline $\begin{array}{l}\text { Chloridium gonytrichii = } \\
\text { "Melanopsammella } \\
\text { gonytrichii" }\end{array}$ & SMH 3785 & AF466085 & - & AF466051 \\
\hline C. lignicola & CBS 143.54 & AF178544 & AF178544 & - \\
\hline Codinaea acaciae & $\begin{array}{l}\text { CPC } 249122=\mathrm{CBS} \\
139907\end{array}$ & - & KR476732 & - \\
\hline Codinaeopsis gonytrichoides & CBS 593.93 & - & AF178556 & - \\
\hline Dendrophoma cytisporoides & CBS 223.95 & JQ889289 & JQ889273 & - \\
\hline Dictyochaeta fertilis & CBS 624.77 & - & AF178540 & - \\
\hline D. simplex & ICMP 14613 & - & EF029193 & - \\
\hline $\begin{array}{l}\text { Dinemasporium } \\
\text { pseudoindicum }\end{array}$ & CBS 127402 & JQ889293 & JQ889277 & - \\
\hline D. pseudostrigosum & CBS 717.85 & JQ889294 & JQ889278 & - \\
\hline D. pseudostrigosum & CBS 825.91 & JQ889295 & JQ889279 & - \\
\hline D. strigosum & CBS 520.78 & JQ889298 & JQ889282 & - \\
\hline Exserticlava vasiformis & TAMA 450 & AB753846 & - & - \\
\hline Gelasinospora tetrasperma & $\begin{array}{l}\text { CBS } 178.33=\text { AFTOL-ID } \\
1287\end{array}$ & DQ470980 & AY681178 & AY681212 \\
\hline Infundibulomyces cupulata & BCC11929 & EF113979 & EF113976 & - \\
\hline Lecythothecium duriligni & CBS 101317 & AF261071 & - & - \\
\hline Menispora ciliata & CBS 122132 & - & EU488737 & - \\
\hline M. manitobaensis & - & - & EU488738 & - \\
\hline $\begin{array}{l}\text { M. pulviscula = "Zignöella } \\
\text { pulviscula" }\end{array}$ & MUCL 15710 & AF466090 & - & AF466059 \\
\hline $\begin{array}{l}\text { M. pulviscula = "Zignöella } \\
\text { pulviscula" }\end{array}$ & SMH 3289 & AF466091 & - & AF466058 \\
\hline $\begin{array}{l}\text { M. pulviscula = "Zignöella } \\
\text { pulviscula" }\end{array}$ & MR 1120 & - & AF178543 & - \\
\hline M. tortuosa & $\begin{array}{l}\text { AFTOL-ID } 278=\text { DAOM } \\
231154\end{array}$ & AY544682 & KT225527 & - \\
\hline M. tortuosa & CBS 214.56 & - & AF178558 & - \\
\hline $\begin{array}{l}\text { Neopseudolachnella } \\
\text { acutispora }\end{array}$ & HHUF 29727 & AB934041 & AB934065 & - \\
\hline N. magnispora & $\begin{array}{l}\text { HHUF } 29977=\text { MAFF } \\
244359\end{array}$ & AB934042 & AB934066 & - \\
\hline N. uniseptata & $\begin{array}{l}\text { HHUF } 29728=\text { MAFF } \\
244360\end{array}$ & AB934043 & AB934067 & - \\
\hline Pseudolachnea fraxini & HHUF 28762 & AB934045 & AB934069 & - \\
\hline P. fraxini & CBS 113701 & JQ889301 & JQ889287 & - \\
\hline P. hispidula & HHUF 30118 & AB934048 & AB934072 & - \\
\hline Pyrigemmula aurantiaca & CPC $18063=$ CBS 126743 & - & HM241692 & - \\
\hline Rattania setulifera & HM171322 & HM171322 & GU191794 & - \\
\hline Sordaria fimicola & CBS 508.50 & AY681160 & AY681188 & AY681228 \\
\hline $\begin{array}{l}\text { Sporoschisma aotearoae = } \\
\text { "Melanochaeta aotearoae" }\end{array}$ & SMH 3551 & AF466082 & - & AF466048 \\
\hline $\begin{array}{l}\text { S. hemipsila = "Melanochaeta } \\
\text { hemipsila" }\end{array}$ & SMH2125 & AY346292 & - & AF466049 \\
\hline
\end{tabular}




\begin{tabular}{|c|c|c|c|c|}
\hline \multirow[t]{2}{*}{ Taxon } & \multirow{2}{*}{ Collection/Isolate no. } & \multicolumn{2}{|c|}{ GenBank accession no. } & \multirow[b]{2}{*}{ TUB } \\
\hline & & LSU & ITS & \\
\hline $\begin{array}{l}\text { Striatosphaeria } \\
\text { codinaeophora }\end{array}$ & SMH 1524 & AF466088 & - & AF466055 \\
\hline Tainosphaeria crassiparies & SMH 1934 & AF466089 & - & AF466056 \\
\hline T. siamensis & MFLUCC 15-0607 & KY212758 & KY212750 & - \\
\hline T. siamensis & MFLU 16-2644 & KT167896 & KT167897 & - \\
\hline Thozetella acerosa & BP 5970 & - & AY330996 & - \\
\hline T. boonjiensis & BP 2383 & - & AY330995 & - \\
\hline T. boonjiensis & $\begin{array}{l}\text { BRIP } 29318 \\
=\text { BP } 2334\end{array}$ & - & AY330994 & - \\
\hline T. cristata & LAMIC0153/13 & - & KJ183032 & - \\
\hline T. fabacearum & MFLUCC 15-1020 & KY212762 & KY212754 & - \\
\hline T. falcata & BP F715 & - & AY331003 & - \\
\hline T. gigantea & BP F712 & - & AY331002 & - \\
\hline T. gigantea & BRIP 29202 = BP F709 & - & AY331001 & - \\
\hline T. havanensis & HER3-4 & - & JQ717009 & - \\
\hline T. havanensis & ICMP: 14173 & - & EF029184 & - \\
\hline T. nivea & - & EU825200 & EU825201 & - \\
\hline T. pinicola & RJ-2008 & EU825195 & EU825197 & EU825199 \\
\hline T. queenslandica & BRIP 29164 = BP F415 & - & AY330997 & - \\
\hline T. queenslandica & BP F612 & - & AY330998 & - \\
\hline Umbrinosphaeria caesariata & CBS 102664 & AF261069 & - & - \\
\hline
\end{tabular}

-Ex-type strains are in bold.

\section{Results}

\section{Phylogenetic analyses}

Phylogenetic analysis of combined LSU, ITS and TUB sequence data was carried out to clarify the phylogenetic placement of our strains within Chaetosphaeriaceae (Table 2). The combined LSU, ITS and TUB dataset consisted of 99 isolates representing 86 species including two outgroup taxa. The aligned dataset comprised 2236 characters (LSU: 1-799, ITS: 800-1303 and TUB: 1304-2236) including gaps. The Bayesian inference yielded trees with similar topologies to support the same terminal clades as obtained from maximum likelihood analysis. The ML trees generated from RAxML are illustrated in Fig 1.

In the phylogenetic analysis, our isolate MFLU 16-2644 clustered together with the ex-type strain of Tainosphaeria siamensis, and formed a sister group to T. crassiparies, which is the generic type. Tainosphaeria, which is basal to Thozetella, is phylogenetically related to Thozetella in the phylogenetic tree (Fig 1). The new isolate Thozetella fabacearum clusters within the genus and is closely related to T. falcata, T. cristata and T. havanensis in the phylogenetic tree. New species Chaetosphaeria garethjonesii shows a greater phylogenetic affinity to C. albida and C. bombycina (Fig 1). Our newly collected strain MFLUCC 15-1011 clustered with the ex-type strain of Chaetosphaeria panamensis (SMH3596) (100\% ML/PP). Chaetosphaeria jonesii (MFLUCC 151015 ) clustered with the $C$. tropicalis (SMH1267), being close to C. lateriphiala F.A. and C. sylvatica (Fig 1). 


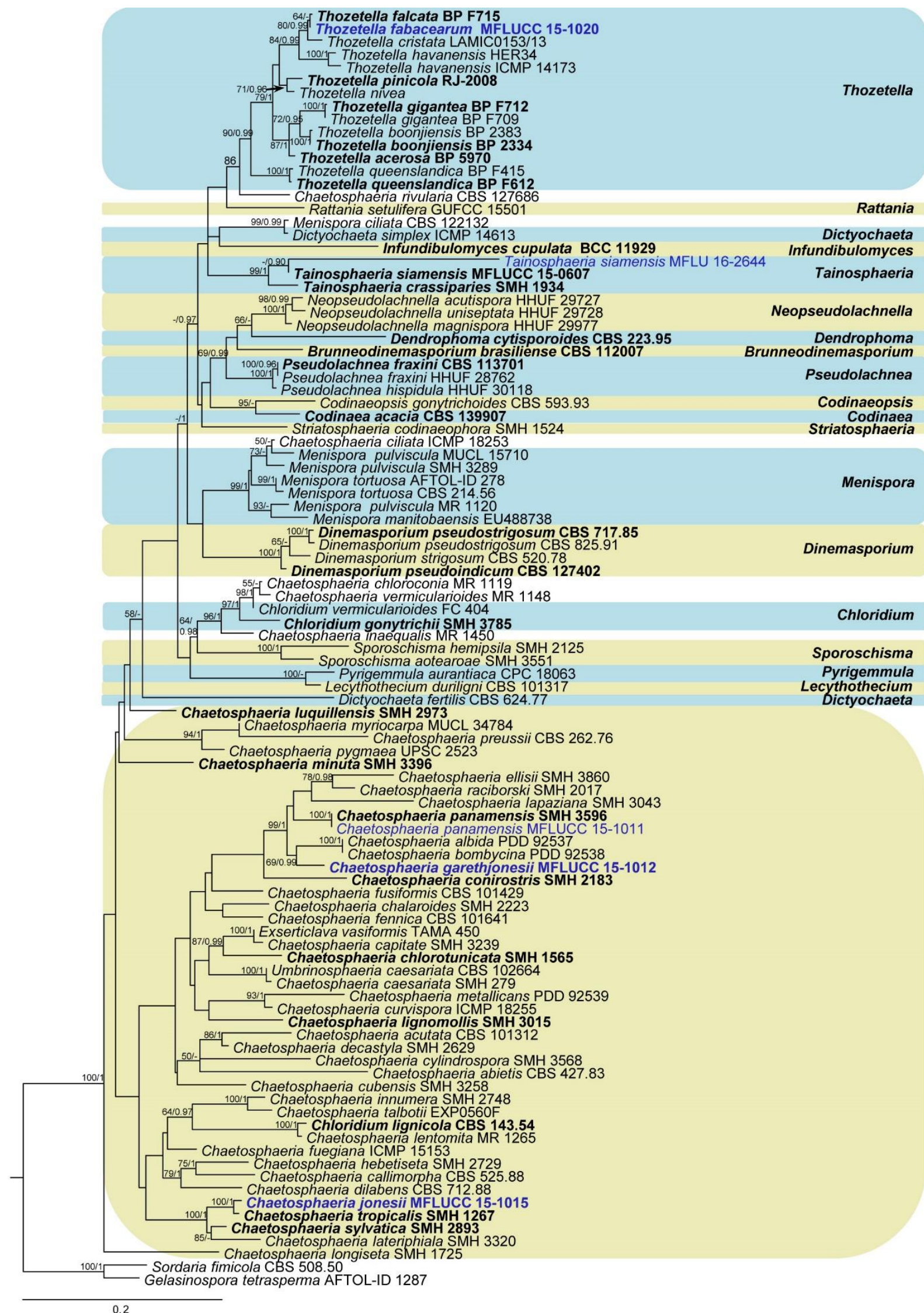

Fig. 1 - Phylogram generated from maximum likelihood analysis of combined LSU, ITS and TUB sequence data from species of Chaetosphaeriaceae. Maximum likelihood bootstrap support values greater than $50 \%$ and Bayesian posterior probabilities (PP) above $90 \%$ are shown near the nodes. The new isolates are in blue and ex-type strains in bold. The tree is rooted with Gelasinospora tetrasperma and Sordaria fimicola. 


\section{Taxonomy}

Chaetosphaeria panamensis Huhndorf \& F.A. Fernández

Figs 2, 3 FOF 02657

Saprobic on dead wood. Sexual morph - Ascomata 180-230 $\mu \mathrm{m}$ diameter, 195-285 $\mu \mathrm{m}$ high, scattered, sparse, superficial, not collapsing when dry, reddish-brown to dark brown, setose, roughwalled, papillate. Setae scattered over entire ascomata, dark brown, stiff, pointed, 60-85 $\mu \mathrm{m}$ long. Peridium 28-45 $\mu \mathrm{m}$ thick, with cells of textura globosa in surface view, 2-layerd in longitudinal section, inner layer 6-10 cells thick, comprising small, brown to dark brown, elongate to polygonal cells, with setae arising from inner layer, outer layer 4-6 cells thick, composed of large isodiametric to polygonal, brown to dark brown cells. Paraphyses 4-4.8 $\mu \mathrm{m}$ wide at the base, tapering towards the apex, numerous, septate. Asci $120-140 \times 10-11.3(\overline{\mathrm{x}}=130.8 \times 10.6, \mathrm{n}=10) \mu \mathrm{m}, 8$-spored, unitunicate, arising from the basal hymenium, cylindrical, rounded at the apex, with a J-, apical ring. Ascospores $60-73 \times 3-4.1(\overline{\mathrm{x}}=68.2 \times 3.5, \mathrm{n}=20) \mu \mathrm{m}$, filiform, loosely fasciculate, straight or slightly curved, 7-septate, without constrictions at the septum, rounded at both ends, apical end broader than the basal end, hyaline, smooth walled. Asexual morph from the culture - colonies on MEA cream coloured to light brown. Conidiophores macronematous, mononematous, flexuous, septate, branched, smooth, pale to moderately brown. Conidiogenous cells $4.3-5.3 \times 1.5-2.1 \mu \mathrm{m}$, phialidic, flask-shaped to clavate, arising on septate, brown conidiophores, hyaline to light brown, guttulate, terminating with a flared conspicuous, cup-shaped collarette. Conidia 14.6-17×10-14.8 $(\overline{\mathrm{x}}=$ $15.6 \times 12.3, \mathrm{n}=20) \mu \mathrm{m}$, enteroblastic, hyaline, 1-celled, globose to subglobose or ellipsoid, guttulate. Aleuriospore-like cells absent.

Culture characters - Twenty-one day old colonies on MEA, 55-58 mm diameter, mostly immersed, with floccose superficial hyphae, margins effuse, light brown from above, reverse dark brown, producing asexual morph after 60 days of incubation in the dark at $28{ }^{\circ} \mathrm{C}$.

Material examined - THAILAND, Chiang Mai Province, garden of Mushroom Research Center, on decorticated twig of Pinus (Pinaceae Spreng. ex F.Rudolphi), 12 July 2015, R.H. Perera, RHP 116 (MFLU 16-1014), living culture, MFLUCC 15-1011.

Notes - Our newly collected strain (MFLUCC 15-1011) clustered with the ex-type strain of Chaetosphaeria panamensis (SMH 3596), collected from wood fragment in Panama. The ascomata, size of asci, ascospores and asexual morph of our strain is typical of $C$. panamensis in the shape and size (Fernández \& Huhndorf 2005) and the ITS molecular data is identical to SMH3596, which is the only gene available for the ex-type. Here, we provide additional LSU, ITS and TUB sequence data for the species. This is the first record of $C$. panamensis for Thailand.

Chaetosphaeria garethjonesii R.H. Perera, Maharachch. \& K.D. Hyde, sp. nov. Fig. 4 Index Fungorum IF552536

FOF 02658

Etymology - In honor of E.B.G. Jones for his work on marine fungi.

Saprobic on a Fabaceae seed pod. Sexual morph - Ascomata brown to dark brown, not collapsing when dry, ovoid to broadly obpyriform, 191-250 $\mu \mathrm{m}$ diameter, 240-257 $\mu \mathrm{m}$ high, superficial, scattered to gregarious, setose, slightly papillate. Setae scattered over entire ascomata, dark brown, stiff, pointed, 38-47 $\mu \mathrm{m}$. Peridium cells $21-59 \mu \mathrm{m}$ thick, with cells textura globosa in surface view, 3-layered in longitudinal section, with inner layer 2-3 cells thick, composed of light brown to hyaline elongate cells, with middle layer 4-6 cells thick, composed of small, brown to 


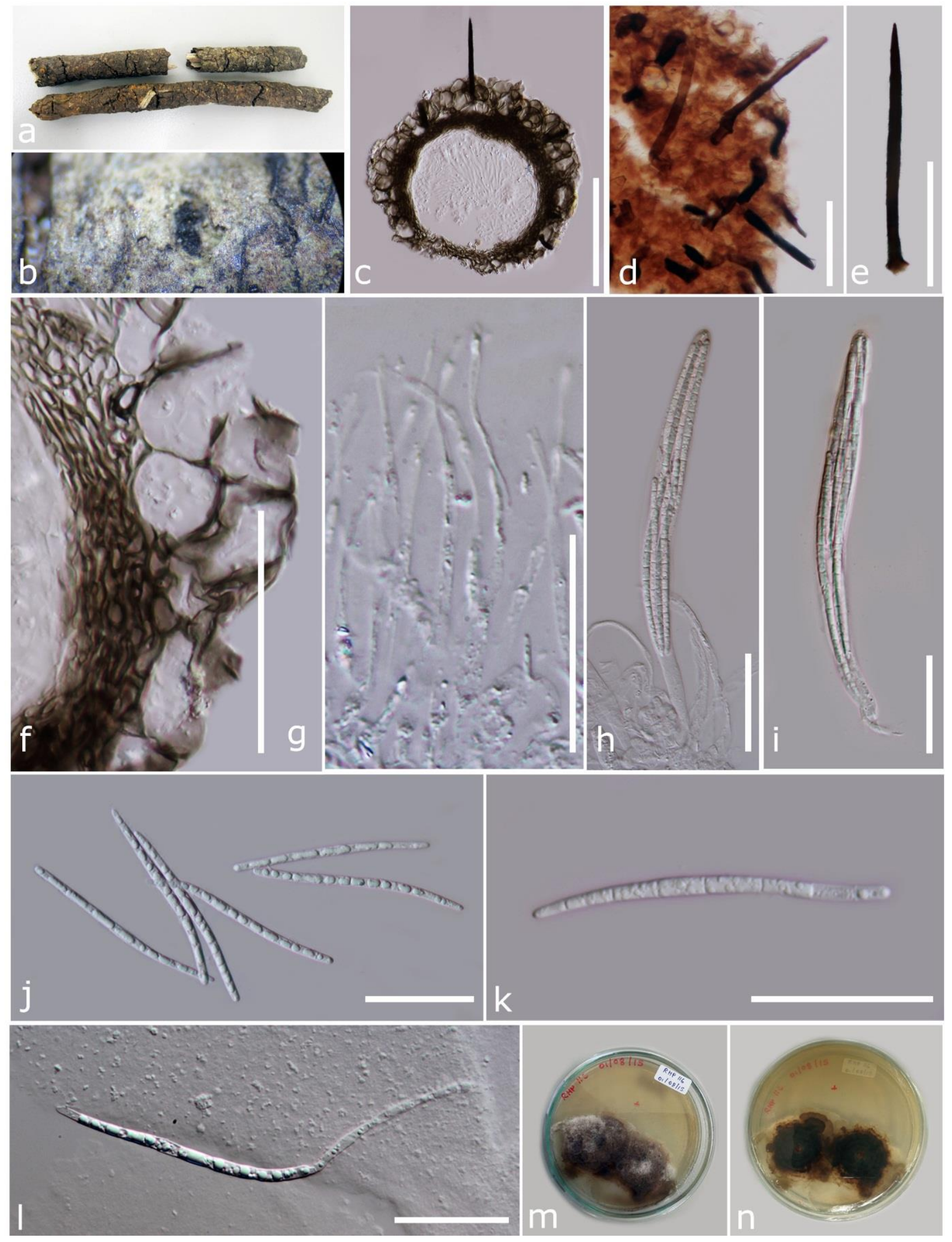

Fig. 2 - Chaetosphaeria panamensis (MFLU 16-1014 a, b). Appearance of ascomata on host substrate. c. Section of ascoma. d. Paraphyses. h, i. Asci. j. Ascospores. k. Germinating ascospore. $\mathrm{m}, \mathrm{n}$. Colony on MEA (above and below). Bars $-\mathrm{c}=100 \mu \mathrm{m}, \mathrm{d}, \mathrm{e}=50 \mu \mathrm{m}, \mathrm{f}-1=20 \mu \mathrm{m}$. 


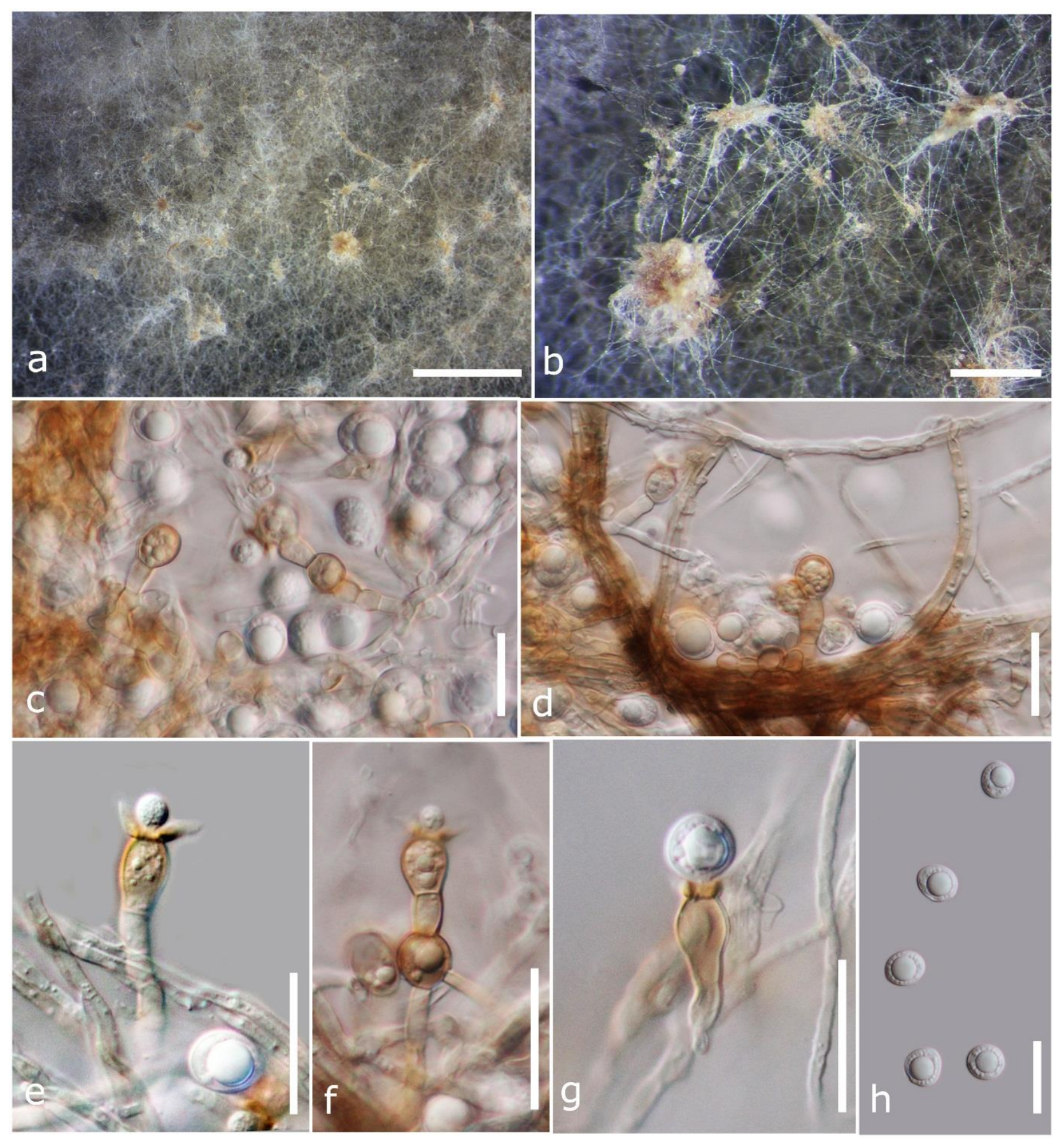

Fig. 3 - Chaetosphaeria panamensis. asexual morph (MFLUCC 15-1011 a, b) Sporulation in MEA. $\mathrm{c}-\mathrm{g}$. Conidiophores with conidia. h. Conidia. Bars $-\mathrm{a}=2 \mathrm{~mm}, \mathrm{~b}=500 \mu \mathrm{m}, \mathrm{c}-\mathrm{h}=20 \mu \mathrm{m}$.

dark brown, elongate to polygonal cells, with outer layer 2-3 cells thick, composed of large isodiametric to polygonal, brown cells. Paraphyses 5.6-8.6 $\mu \mathrm{m}$ wide, of variable length, simple, sparse, hyaline, unbranched, tapering towards the apex, septate. Asci $120-152 \times 10.7-13.3(\overline{\mathrm{x}}=137 \times 12$ $\mu \mathrm{m}, \mathrm{n}=20) \mu \mathrm{m}, 8$-spored, unitunicate, cylindrical, pedicellate, with rounded apex, with a thin, J-, apical ring. Ascospores $63.3-75 \times 2.3-3.7(\overline{\mathrm{x}}=69.5 \times 3.1 \mu \mathrm{m}, \mathrm{n}=30) \mu \mathrm{m}$, fasciculate, straight to gently curved, with rounded ends, slightly tapering to base, 7-septate, sometimes slightly constricted at septa, hyaline, smooth-walled, without a gelatinous sheath. Asexual morph - Undetermined. 
Culture characters - Twenty-one day old colonies on MEA 60-76 mm diameter, flat, lacking aerial mycelium, margins effuse, dark brown at margins, gray to white at the center from above, reverse dark brown.

Material examined - THAILAND, Chiang Mai Province, on a Fabaceae seed pod, 19 July 2015, R.H. Perera, RHP 115 (MFLU 16-1019, holotype), ex-type living culture, MFLUCC 15-1012.

Notes - Chaetosphaeria garethjonesii is a distinct species in the genus as supported by molecular and morphological characters. In the phylogenetic tree, $C$. garethjonesii is sister to $C$. albida T.J. Atk. et al. and C. bombycina T.J. Atk. et al. (Fig 1). Chaetosphaeria garethjonesii differs from $C$. albida and C. bombycina in ascomatal morphology. Chaetosphaeria albida and $C$. bombycina are characterized by almost white or light fawn-grey, translucent or reflective ascomatal with walls lacking setae, while $C$. garethjonesii has brown to dark brown ascomata with setose, rough walls (Atkinson et al. 2007). Ascospore septation in C. albida is also less than that in C. bombycina (7 vs. 11; Atkinson et al. 2007).

Chaetosphaeria jonesii R.H. Perera, Maharachch. \& K.D. Hyde, sp. nov. Fig. 5 Index Fungorum IF552574

FOF 02659

Etymology - In honour of E.B.G. Jones for his work on tropical mycology.

Saprobic on wood. Sexual morph - Ascomata 102-250 $\mu \mathrm{m}$ diameter, 142-263 $\mu \mathrm{m}$ high, superficial, arranged in clusters, subglobose to globose, dark brown, surface rough, ostiolate, surrounded by setae. Ostiole periphysate. Setae brown, multi-septate, sinuous, cylindrical, with a rounded apex, arising from base of ascomata and abundant on the substrate. Peridium composed of dark brown cells of textura angularis in surface view, 11-16 $\mu \mathrm{m}$ thick in longitudinal section, 2 layered, inner layer 3-5 cells thick, composed of hyaline elongate cells of textura angularis, with outer layer 4-7 cells thick, composed of brown to dark brown, globose to polygonal cells. Paraphyses 3.9-4.6 $\mu \mathrm{m}$ wide, sparse, simple, septate. Asci $69-90 \times 8.5-11(\overline{\mathrm{x}}=80 \times 10 \mu \mathrm{m}, \mathrm{n}=20) \mu \mathrm{m}, 8$-spored, unitunicate, cylindrical-clavate, short-pedicellate, with a thin, J-, apical ring. Ascospores 16.2$17.7 \times 2.8-3.6(\overline{\mathrm{x}}=19.5 \times 3.6 \mu \mathrm{m}, \mathrm{n}=20) \mu \mathrm{m}$, overlapping biseriate, hyaline to pale brown, fusiform, 3 -septate, curved, smooth-walled. Asexual morph - Undetermined.

Material examined - THAILAND, Chiang Mai, on decorticated wood, 5 August 2015, S. Boonmee, RHP 121 (MFLU 16-1020, holotype), ex-type living culture, MFLUCC 15-1015.

Notes - Maximum likelihood and Bayesian analyses of combined LSU, ITS and TUB sequence data shows, Chaetosphaeria jonesii (MFLUCC 15-1015) clustered with the ex-type strain of $C$. tropicalis F.A. Fernández \& Huhndorf (SMH 1267) which was earlier collected from Puerto Rico, on a wood fragment. We observed that the asci $(69-90 \times 8.5-11$ vs. $100-138 \times 10-12.5 \mu \mathrm{m}$; Fernández \& Huhndorf 2005) and ascospores (16.2-17.7×2.8-3.6 vs. 19-26×3.2-6.3 $\mu$ m; Fernández $\&$ Huhndorf 2005) of our strain are smaller than C. tropicalis. Chaetosphaeria jonesii is also phylogenetically and morphologically close to $C$. lateriphiala F.A. Fernández \& Huhndorf and $C$. sylvatica F.A. Fernández \& Huhndorf (Fig 1). However, the ascomata $(102-250 \times 142-263 \mu \mathrm{m})$, asci $(69-90 \times 8.5-11 \mu \mathrm{m})$ and ascospores $(16.2-17.7 \times 2.8-3.6 \mu \mathrm{m})$ of $C$. jonesii are smaller than those of C. lateriphiala (ascomata: 200-248×234-307 $\mu \mathrm{m}$, asci: 95-113×10-12.5 $\mu \mathrm{m}$, ascospores: 1824×4.5-6 $\mu \mathrm{m}$; Fernández \& Huhndorf 2005). Chaetosphaeria jonesii also can be distinguished from C. sylvatica by its smaller ascomatal size $(102-250 \times 142-263 \mu \mathrm{m}$ vs. $264-302 \times 269-292 \mu \mathrm{m}$; Fernández \& Huhndorf 2005), smaller asci (69-90 $\mu$ m vs. 95-115 $\mu$ m; Fernández \& Huhndorf 

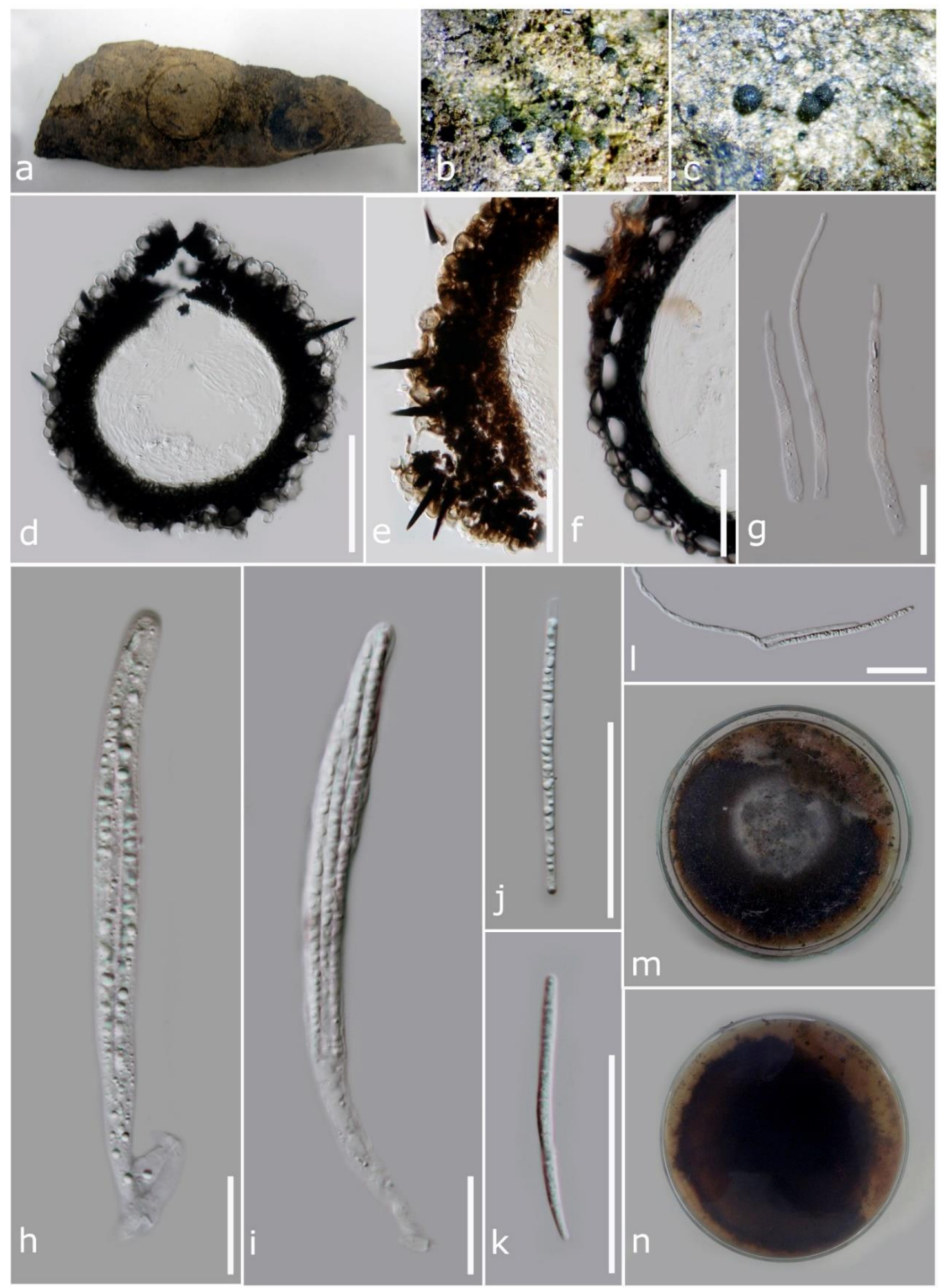

Fig 4 - Chaetosphaeria garethjonesii (MFLU 16-1019, holotype a-c). Appearance of ascomata on host substrate. d. Section of ascoma. e. Peridium with ascomatal setae. f. Peridium. g. Paraphyses. h, i. Asci. j, k. Ascospores. 1. Germinating ascospore. m, n. Colony on MEA (above and below views). Bars $-\mathrm{b}=500 \mu \mathrm{m}, \mathrm{d}=100 \mu \mathrm{m}, \mathrm{e}=50 \mu \mathrm{m}, \mathrm{f}-\mathrm{i}=20 \mu \mathrm{m}, \mathrm{j}, \mathrm{k}=50 \mu \mathrm{m}, \mathrm{l}=20 \mu \mathrm{m}$.

2005) and thinner ascospores (2.8-3.6 vs. 4-5.5; Fernández \& Huhndorf 2005). By taking into account the morphological and molecular data we introduce Chaetosphaeria jonesii as a new species. 
Saprobic on seeds and wood. Sexual morph - Undetermined. Asexual morph - Colonies on natural substrate, effuse, superficial, hairy, dark brown, in groups. Conidiophores mononematous, macronematous, subcylindrical, flexuous or straight, septate, unbranched, brown, becoming light brown towards the apex, smooth-walled, tapering to a terminal single phialide, 5-6.4 $\mu \mathrm{m}$ at the base. Conidiogenous cells phialidic cylindrical to clavate, light brown, smooth walled, with a periclinal thickened, flared, collarette. Collarette funnel-shaped, 4-6.2 $\mu \mathrm{m}$ wide at the opening, hyaline. Conidia 17.5-20.5 $\times 3.2-3.4(12.5 \times 1.8) \mu \mathrm{m}$, enteroblastic, naviculate to fusiform or cylindrical, equilateral, hyaline, both ends obtuse to subobtusely rounded, sometimes basal end truncate, with single setula at both ends, 7.8-9.1 $\mu \mathrm{m}$ long.

Culture characters - Cultures were not obtained.

Material examined - THAILAND, Chiang Mai Province, on a Fabaceae seed pod, 20 December 2015, R.H. Perera, DeloL 8 (MFLU 16-2644).

Notes - DNA was extracted directly from the colonies growing on the natural substrate. Phylogenetic analysis of combined LSU, ITS and TUB sequence data confirms our strain clusters with the ex-type strain of Tainosphaeria siamensis which was isolated from Thailand (Liu et al. 2016). It is similar to the ex-type strain of T. siamensis in conidiophore morphology, conidial size and shape. Tainosphaeria siamensis resembles the asexual morph of $T$. crassiparies, in terms of similar conidiophore morphology and conidial appendages. It can be distinguished from the latter by equilateral (vs. inequilateral) larger conidia (vs. 10.5-14.8×2-3 $\mu \mathrm{m}$ ) and conidiogenesis (phialidic vs. percurrent) (Fernández \& Huhndorf 2005, Liu et al. 2016).

Thozetella fabacearum R.H. Perera \& K.D. Hyde, sp. nov.

Figs 7, 8 Index Fungorum IF552537

FOF 02660

Etymology - Referring to the host family, Fabaceae.

Saprobic on a Fabaceae seed pods. Sexual morph - Undetermined. Asexual morph from the natural substrate - Colonies effuse, superficial, sporodochial, white. Sporodochia cylindrical or subulate, scattered, sessile, superficial, of cream white mass. Microawns 33-60 $\mu \mathrm{m}$ long, 3-5.3 $\mu \mathrm{m}$ wide, visible as small hairs in mass on the natural substrate, aseptate, smooth-walled, thick-walled, hyaline, variously-shaped, sigmoid or sickle-shaped, sometimes L-shaped. Conidia 13.2-17.2×1.9$2.4(\overline{\mathrm{x}}=15.5 \times 2.1 \mu \mathrm{m}, \mathrm{n}=30) \mu \mathrm{m}$, falcate, inequilateral, with rounded apical end, truncate at basal end, hyaline, smooth-walled, with a single filiform setula at each end, 3.6-9 $\mu \mathrm{m}$ long. Asexual morph from the culture - Conidiomata funnel-shaped, synnematous, abundant, elongated, brown to dark brown, with hyaline to ash apices, branched. Conidiophores macronematous, brown, cylindrical, septate, branched, densely compacted along the synnemata axis, smooth-walled. Conidiogenous cells 1.7-2.8 $\mu \mathrm{m}$ wide, phialidic, hyaline, smooth-walled, thick-walled. Microawns 32.8-56.4 $\mu \mathrm{m}$ long, 1.7-2.7 $\mu \mathrm{m}$ wide, aseptate, smooth-walled, hyaline, variously shaped, predominantly L-shaped, sometimes sigmoid or sickle-shaped. Conidia 11.6-14.7 $\times 2.2-3.4(\overline{\mathrm{x}}=13.3 \times 2.6 \mu \mathrm{m}, \mathrm{n}=20) \mu \mathrm{m}$, naviculate to fusiform or ellipsoid, inequilateral, with rounded apical end, truncate at basal end, hyaline, smooth-walled, with a single filiform setula at each end, 2.1-3.4 $\mu \mathrm{m}$ long.

Culture characters - 21 day old colonies on MEA $35 \mathrm{~mm}$, margins effuse, gray to dark-brown, flat, lacking aerial mycelium, producing synnemata after 150 days of incubation in the dark at $28^{\circ} \mathrm{C}$, reverse dark-brown to black. 


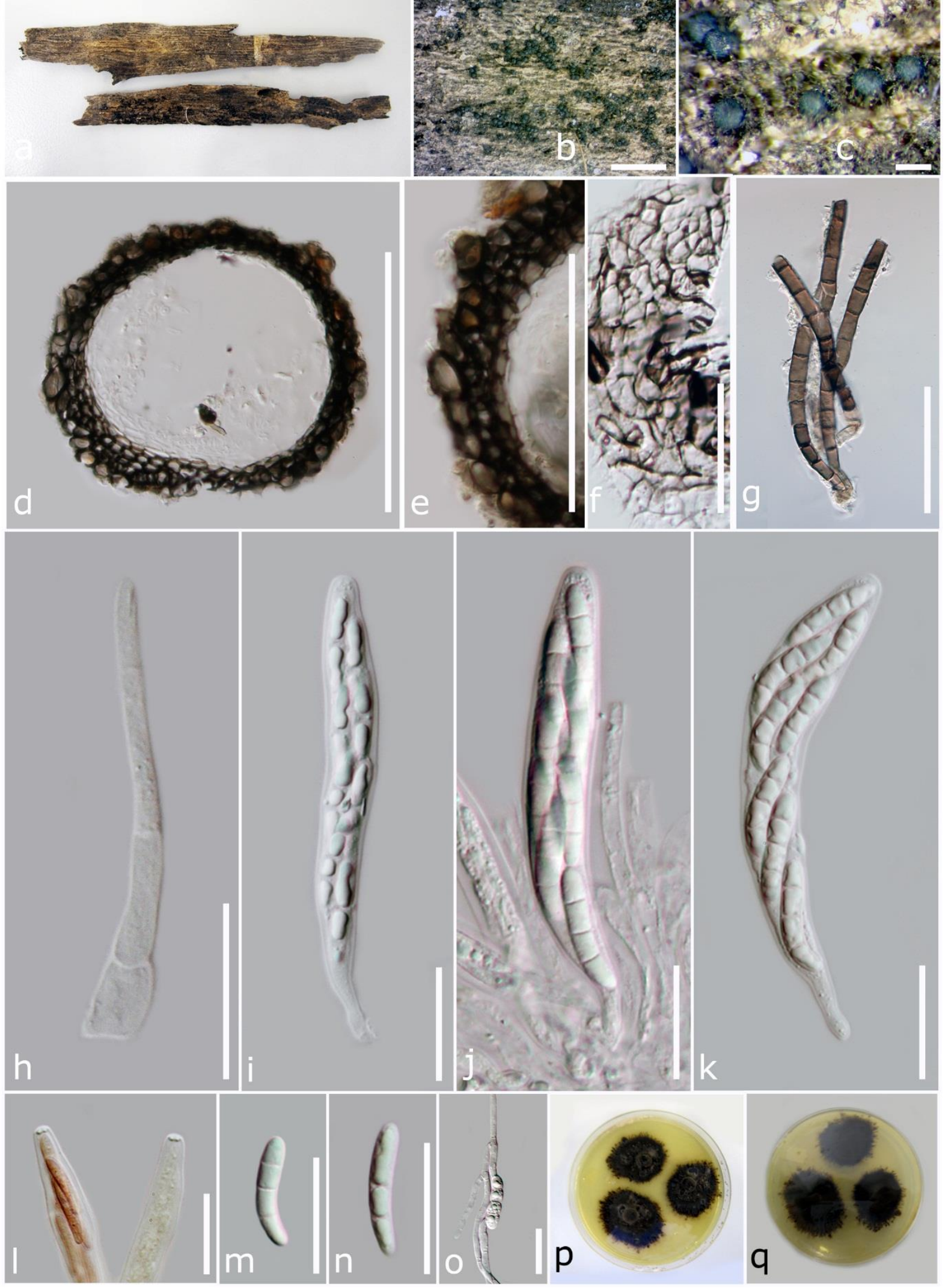

Fig. 5 - Chaetosphaeria jonesii (MFLU 16-1020, holotype) a. Herbarium specimen. b, c. Appearance of ascomata on host substrate. d. Section of ascoma. e. Peridium. f. Peridium in surface view. g. Setae. h. Paraphyses. i, j. Immature and mature asci. k. Close up of apical asci in Melzer's reagent. 1. Ascospores. m. Germinating ascospore. Bars $-\mathrm{b}, \mathrm{c}=2 \mathrm{~mm}, \mathrm{~d}=100 \mu \mathrm{m}, \mathrm{e}=50 \mu \mathrm{m}, \mathrm{f}-\mathrm{o}=20 \mu \mathrm{m}$. 


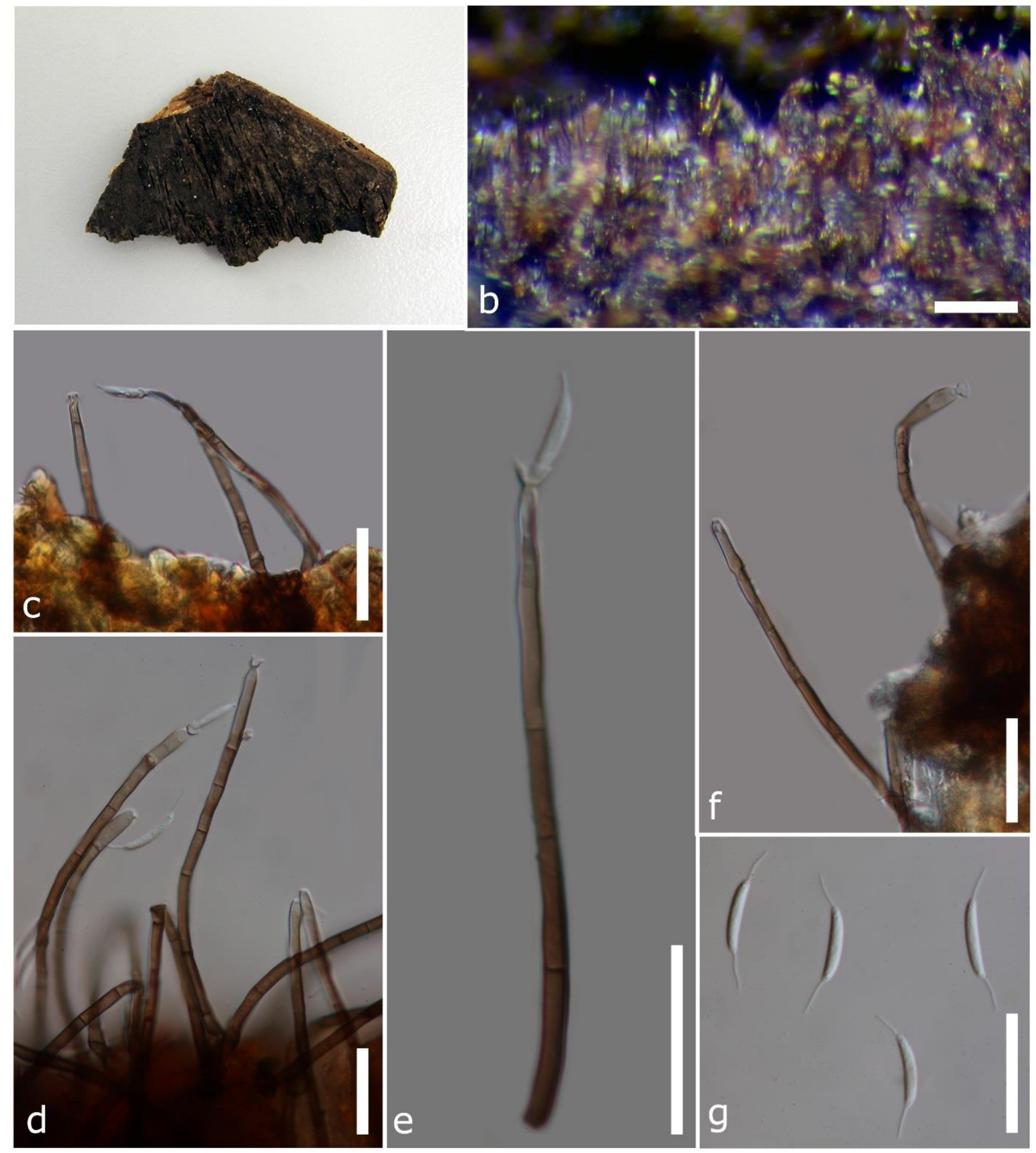

Fig. 6 - Tainosphaeria siamensis (MFLU 16-2644 a). Herbarium specimen. b. Conidiophores on host substrate. c-e. Conidiophore with developing conidium. f. Apical phialides. g. Conidia. Bars $\mathrm{b}=50 \mu \mathrm{m}, \mathrm{c}-\mathrm{g}=20 \mu \mathrm{m}$.

Material examined - THAILAND, Phang-nga Province, Mueang Phang-nga District, Tham Nam Phut, on a Fabaceae seed pod, 7 December 2014, M. Dayarathne RHP 126 (MFLU 16-1021, holotype), ex-type living culture, MFLUCC 15-1020.

Notes - In this paper, we introduce Thozetella fabacearum as a new species which was collected from Phang-nga Province, Thailand. Maximum likelihood and Bayesian analyses of combined LSU, ITS and TUB sequence data (Fig 1) showed that T. fabacearum is closest to T. falcata B.C. Paulus et al. and T. cristata Piroz. \& Hodges with moderate support. Thozetella falcata 


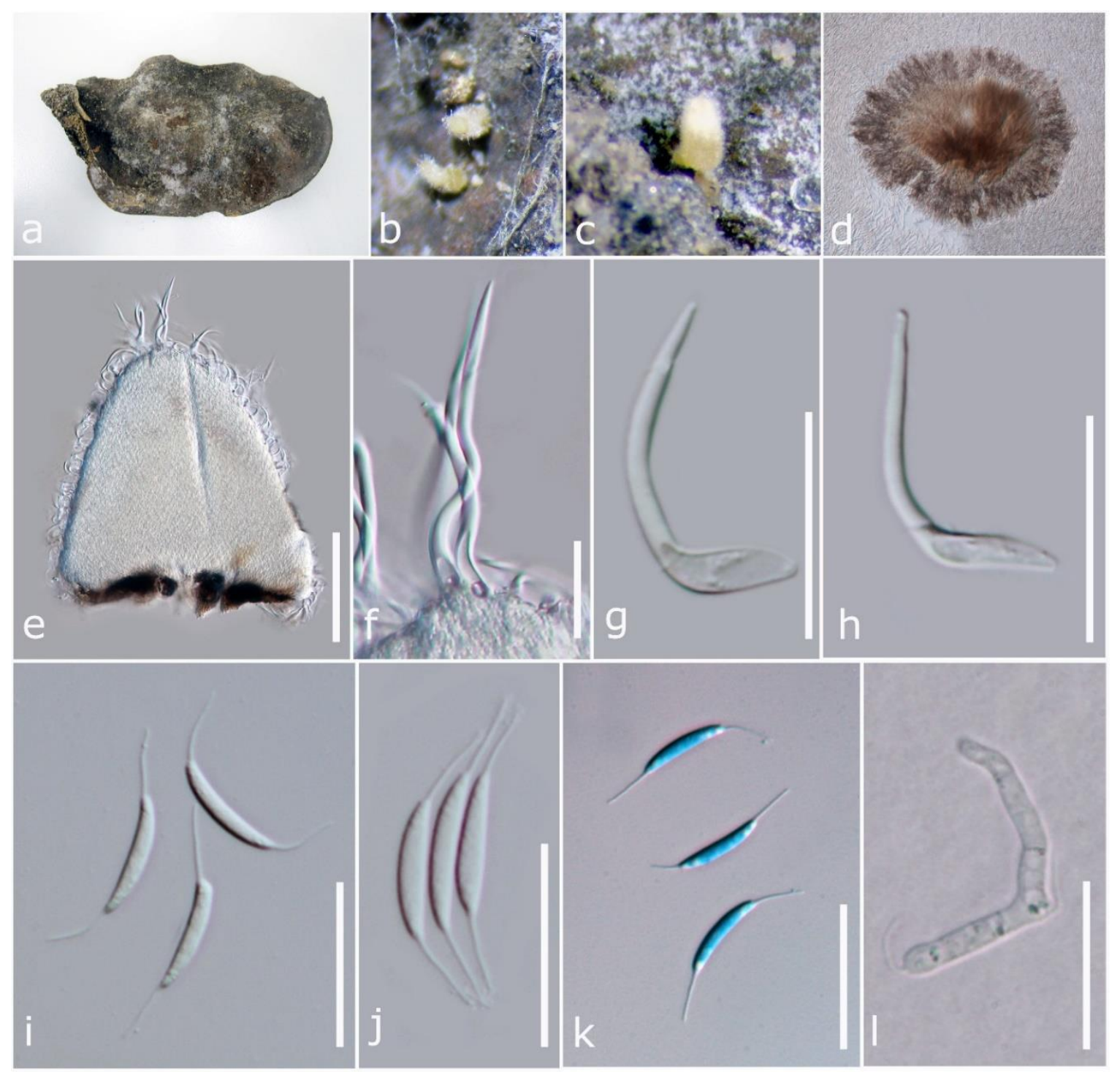

Fig. 7 - Thozetella fabacearum (MFLU 16-1021, holotype) a. Herbarium specimen. b, c. Appearance of conidiomata on host substrate. d. Synnemata, circular in shape. e. Section through synnemata. fh. Microawns. i-k. Conidia ( $\mathrm{k}$ in Cresol blue). 1. Germinating conidium. Bars $-\mathrm{d}=100 \mu \mathrm{m}$, e-k $=$ $20 \mu \mathrm{m}, 1=10 \mu \mathrm{m}$.

only has ITS sequence data for comparison. Therefore, it is not well-separated from Thozetella fabacearum in the phylogeny. However, T. fabacearum can easily be distinguished from $T$. falcata by the conidiomatal morphology and shorter microawns (33-60 vs. 40-95 $\mu \mathrm{m}$ ) (Paulus et al. 2004). Thozetella fabacearum produce sporodochia on the natural substrate and synnemata in the culture, while T. falcata and T. cristata produce synnemata on the natural substrate. Thozetella tocklaiensis (Agnihothr.) Piroz. \& Hodges is the only Thozetella species producing sporodochia on the natural substrate and synnemata in culture (Barbosa et al. 2011, Paulus et al. 2004). However, T. fabacearum differs from $T$. tocklaiensis in having larger conidia $(13.2-17.2 \times 1.9-2.4$ vs. $9-13 \times 1.5-3 \mu \mathrm{m})$ and smaller microawns (33-60×3-5.3 vs. 18-38×1.5 $\mu \mathrm{m}$ ) (Agnihothrudu 1958, Pirozynski \& Hodges CS Jr 1973). Although, the microawns size in T. fabacearum and T. cristata overlap, T. fabacearum differs in having larger conidia (13.2-17.2×1.9-2.4 $\mu \mathrm{m}$ as compared to $11.5-14.5 \times 2.3-2.7 \mu \mathrm{m}$ in $T$. cristata) (Barbosa et al. 2011). 

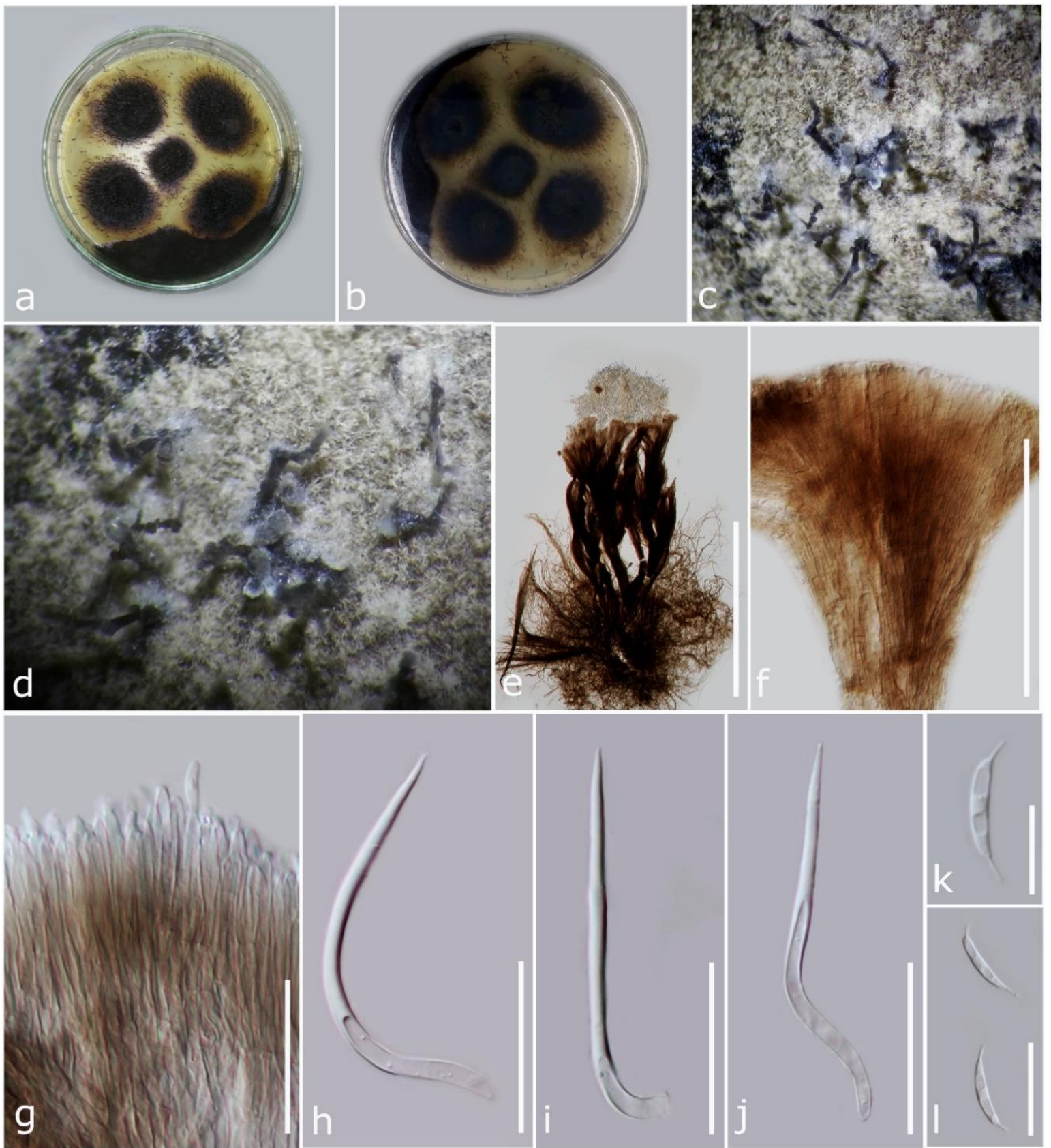

Fig. 8 - Thozetella fabacearum in culture (MFLUCC 15-1020) ex-type culture a, b. Sporulation on MEA. c, d. Appearance of conidiomata on MEA. e. Synnemata. f. Closely packed conidiophores. g. Conidiogenous cells. $\mathrm{h}-\mathrm{j}$. Microawns. $\mathrm{k}$, l. Conidia. Bars $-\mathrm{e}=500 \mu \mathrm{m}, \mathrm{f}=100 \mu \mathrm{m}, \mathrm{g}-\mathrm{j}=10 \mu \mathrm{m}, \mathrm{k}$ $=10 \mu \mathrm{m}, 1=20 \mu \mathrm{m}$.

\section{Discussion}

Fabaceae (legume family) is the third largest family of flowering plants which is diverse and cosmopolitan (Gepts et al. 2005). They are economically important as legume crops, medicinal plants and fodder (Gepts et al. 2005, Gao et al. 2010). Fabaceae members are associated with rhizobial symbionts and play important role in the environment by fixing nitrogen (Gepts et al. 2005). The fruit pod is composed of a single seed-bearing carpel that splits open along two seams. Legume pods contain cellulose, hemicelluloses and lignin which can also provide substrates for fungal growth (Paula et al. 2011). Two new taxa Tainosphaeria crassiparies and Cirrenalia nigrospora were 
described from seed pods of Hymenaea and Delonix regia respectively (Somrithipol et al. 2002, Fernández \& Huhndorf 2005). Moreover, a number of chaetosphaeriaceous taxa (ie. Chloridium macrocladum (=Gonytrichum macrocladum), Chloridium sp., Dictyochaeta sp., Sporoschisma nigroseptatum, S. saccardoi, S. hemipsila and Thozetella nivea) have been isolated from Fabaceae seed pods in Thailand (Somrithipol et al. 2002).

The family Chaetosphaeriaceae M.V. Locq. was proposed without any description by Locquin (1984) to accommodate five genera including Chaetosphaeria, Zignöella Sacc, Niesslia Auersw., Rhagadostoma Körb, and Loramyces W. Weston. This was not considered as a validly published family (Hawksworth \& David 1989 - Art. 36.1, Grueter et al. 1994). Réblová et al. (1999) therefore re-introduced the family based on Chaetosphaeria Tul. \& C. Tul., to accommodate six other genera: Ascocodinaea, Melanochaeta, Melanopsammella, Porosphaerella, Porosphaerellopsis and Striatosphaeria. Réblová et al. (1999) maintained Chaetosphaeriaceae in Sordariales based on morphology. Huhndorf (2004) placed the family in Chaetosphaeriales, based on LSU sequence data. Subsequently more genera were added to the family and, currently, there are 38 accepted genera (Index Fungorum 2016, Liu et al. 2016, Maharachchikumbura et al. 2016). Maharachchikumbura et al. (2016) noted the taxonomic confusion of genera in the family and the importance of a monograph with molecular support for accepted genera.

In this study, we introduce one new species of Thozetella, two new species of Chaetosphaeria, and one new record of Chaetosphaeria for Thailand. Here we illustrate Tainosphaeria siamensis, which is the first record on Fabaceae seed pods. Fungal identifications are based on morphology and analysis of combined LSU, ITS and TUB sequence data. Thozetella fabacearum is distinct from other Thozetella species, since it produces sporodochia on natural substrates and synnemata in vitro on MEA. This has only been observed in Thozetella tocklaiensis (Agnihothr.) Piroz. \& Hodges (Paulus et al. 2004, Barbosa et al. 2011). Chaetosphaeria species seems to be polyphyletic within the family, and these finding are similar to those obtained by Jeewon et al. (2009) and Crous et al. (2012) using ITS and LSU sequence data. The generic type strain of Chaetosphaeria (C. innumera) lacks ex-type sequence data. Therefore, it is essential to re-collect, epitypify (sensu Ariyawansa et al. 2014) and sequence the types of genera to resolve the phylogenetic confusion.

\section{Acknowledgements}

We honour Professor E.B. Gareth Jones for his dedication to tropical mycology and inspirations to young mycologists. R.H. Perera thanks Professor E.B. Gareth Jones for the award of a PhD scholarship. Zuo-Yi Liu thanks the featured microbial resources and diversity investigation in Southwest Karst area (2014FY120100). K.D. Hyde would like to thank the Chinese Academy of Sciences, project number 2013T2S0030, for the award of a Visiting Professorship for Senior International Scientists at Kunming Institute of Botany. R.H. Perera is grateful to Rajesh Jeewon for providing needful literature. Hiran Ariyawansa, Dhanushka Wanasinghe, Asha Dissanayake and Anupama Daranagama are thanked for providing assistance and valuable suggestions.

\section{References}

Agnihothrudu V. 1958 - Notes on fungi from North East India. I. A new genus of Tuberculariaceae. Mycologia 50, 571-579.

Agnihothrudu V. 1962 - A comparison of some techniques for the isolation of fungi from tea soils. Mycopathology 16, 234-242. 
Allegrucci N, Cazau MC, Cabello MN, Arambari AM. 2004 - Thozetella buxifolia sp. nov. - a new hyphomycete from Argentina. Mycotaxon 90, 275-279.

Ariyawansa HA, Hawksworth DL, Hyde KD, Jones EBG et al. 2014 - Epitypification and neotypification: guidelines with appropriate and inappropriate examples. Fungal Diversity 69, 57-91.

Atkinson TJ, Miller AN, Huhndorf SM, Orlovich DA. 2007 - Unusual new Chaetosphaeria species from New Zealand: Intrafamilial diversity and elucidations of the ChaetosphaeriaceaeLasiosphaeriaceae relationship (Sordariomycetes, Ascomycotina). New Zealand Journal of Botany 45, 685-706.

Barbosa FR, Silva SSD, Fiuza PO, Gusmão LFP. 2011 - Conidial fungi from the semi-arid Caatinga biome of Brazil. New species and records for Thozetella. Mycotaxon 115, 327-334.

Barr ME. 1990 - Prodromus to nonlichenized, pyrenomycetous members of class Hymenoascomycetes. Mycotaxon 39, 43-184

Chomnunti P, Hongsanan S, Hudson BA, Tian Q et al. 2014 - The sooty moulds. Fungal Diversity 66, 1-36.

Crous PW, Verkley GJM, Christensen M, Castañeda-Ruiz RF, Groenewald JZ. 2012 - How important are conidial appendages? Persoonia 28, 126-137.

Delgado-Rodrígues G, Mena-Portales J. 2004 - Hifomicetos Aero-acuáticos e Ingoldianos de la reserve de la Biosfera Sierra del Rosario (Cuba). Biological Society of Mycology Madrid 28, 105-113.

Fernández FA, Huhndorf SM. 2005 - New species of Chaetosphaeria, Melanopsammella and Tainosphaeria gen. nov. from the Americas. Fungal Diversity 18, 15-57.

Fernández FA, Miller AN, Huhndorf SM, Lutzoni FM et al. 2006 - Systematics of the genus Chaetosphaeria and its allied genera: morphological and phylogenetic diversity in north temperate and neotropical taxa. Mycologia 98, 121-130.

Gams W, Holubová-Jechová V. 1976 - Chloridium and some other dematiaceous hyphomycetes growing on decaying wood. Studies in Mycology 13, 1-99.

Gao T, Yao H, Song J, Liu C et al. 2010 - Identification of medicinal plants in the family Fabaceae using a potential DNA barcode ITS2. Journal of Ethnopharmacology 130, 116-21.

Gepts P, Beavis WD, Brummer EC, Shoemaker RC et al. 2005 - Legumes as a model plant family. Genomics for food and feed report of the cross-legume advances through genomics conference. Plant Physiology 137, 1228-35.

Glass NL, Donaldson GC. 1995 - Development of primer sets designed for use with the PCR to amplify conserved genes from filamentous ascomycetes. Applied and Environmental Microbiology 61, 1323-1330.

Grueter W, Barrie FR, Bürdet HM, Chaloner WG et al. 1994 - International Code of Botanical Nomenclature: Tokyo Code. International Association for Plant Taxonomy, Berlin.

Hawksworth DL, David JC. 1989 - Family names. Index of Fungi Supplement - C.A.B. International. Wallingford, U.K.

Ho WH, Hyde KD, Hodgkiss IJ. 2001 - Fungal communities on submerged wood from streams in Brunei, Hong Kong, and Malaysia. Mycological Research 105, 1492-1501.

Huelsenbeck JP, Ronquist F. 2001 - MRBAYES: Bayesian inference of phylogenetic trees. Bioinformatics 17, 754-755.

Huhndorf SM, Miller AN, Fernández FA. 2004 - Molecular systematics of the Sordariales: the order and the family Lasiosphaeriaceae redefined. Mycologia 96, 368-387. 
Huhndorf SM, Fernandez F, Taylor JE, Hyde KD. 2001 - Two pantropical Ascomycetes: Chaetosphaeria cylindrospora sp. nov. and Rimacomus, a new genus for Lasiosphaeria jamaicensis. Mycologia 93, 1072-1080.

Index Fungorum 2016 - www.indexfungorum.org.

Jayasiri SC, Hyde KD, Ariyawansa HA, Bhat DJ et al. 2015 - The Faces of Fungi database: fungal names linked with morphology, phylogeny and human impacts. Fungal Diversity 74, 3-18.

Jeewon R, Yeung SYQ, Hyde KD. 2009 - A novel phylogenetic group within Thozetella (Chaetosphaeriaceae): a new taxon based on morphology and DNA sequence analyses. Canadian Journal of Microbiology 55, 680-687.

Kuntze O 1891 - Revisio generum plantarum 2, 375-1011.

Liu JK, Yang J, Maharachchikumbura SS, McKenzie EHC et al. 2016 - Novel chaetosphaeriaceous hyphomycetes from aquatic habitats. Mycological Progress 15, 1157-1167.

Locquin MV. 1984 - Mycologie generale et structurale. Masson, Paris.

Maharachchikumbura SSN, Hyde KD, Jones EBJ, McKenzie EHC et al. 2016 - Families of Sordariomycetes. Fungal Diversity 79, 1-317.

Maharachchikumbura SSN, Hyde KD, Jones EBG, McKenzie EHC et al. 2015 - Towards a natural classification and backbone tree for Sordariomycetes. Fungal Diversity 72, 199-301.

Morris EF. 1956 - Tropical Fungi Imperfecti. Mycologia 48, 728-737.

Nylander JAA. 2004 - MrModeltest v2. Program distributed by the author. Evolutionary Biology Centre, Uppsala University, Sweden.

Paula LE, Trugilho PF, Napoli A, Bianchi ML. 2011 - Characterization of residues from plant biomass for use in energy generation. Cerne 17, 237-46.

Paulus BC, Gadek P, Hyde KD. 2004 - Phylogenetic and morphological assessment of five new species of Thozetella from an Australian rainforest. Mycologia 96, 1074-1087.

Pinruan U, Hyde KD, Lumyong S, McKenzie EHC, Jones EBG. 2007 - Occurrence of fungi on tissues of the peat swamp palm Licuala longicalycata. Fungal Diversity 25, 157-173.

Pirozynski KA, Hodges CS Jr. 1973 - New hyphomycetes from South Carolina. Canadian Journal of Botany 51, 151-173.

Réblová M, Barr ME, Samuels GJ. 1999 - Chaetosphaeriaceae, a new family for Chaetosphaeria and its relatives. Sydowia 51, 49-70.

Silva P Da, Grandi RAP. 2011 - A new species of Thozetella (anamorphic fungi) from Brazil. Cryptogamie Mycologie 32, 359-63.

Silva P Da, Grandi RAP. 2013 - Taxonomic studies of Thozetella Kuntze (anamorphic Chaetosphaeriaceae, Ascomycota). Nova Hedwigia. 97, 361-99.

Silvestro, D, Michalak I. 2011 - raxmlGUI: a graphical front-end for RAxML. Organisms Diversity and Evolution 12, 335-337.

Sivichai S, Jones EBG, Hywel-Jones N. 2002 - Fungal colonization of wood in a freshwater stream at Tad Ta Phu, Khao Yai National Park, Thailand. Fungal Diversity 10, 113-129.

Somrithipol S, Jones EBG, Hywel-Jones NL. 2002 - Fungal diversity and succession on seed pods of Delonix regia (Leguminosae) exposed in a tropical forest in Thailand. Fungal Diversity 10, 131-139.

Sutton BC, Cole GT. 1983 - Thozetella (Hyphomycetes): an exercise in diversity. Transactions of the British Mycological Society 81, 97-107. 
Tamura K, Peterson D, Peterson N, Stecher G et al. 2011 - MEGA5: molecular evolutionary genetics analysis using maximum likelihood, evolutionary distance, and maximum parsimony methods. Molecular Biology and Evolution 28, 2731-2739.

Vilgalys R, Hester M. 1990 - Rapid genetic identification and mapping of enzymatically amplified ribosomal DNA from several Cryptococcus species. The Journal of Bacteriology 172, 42384246.

Waipara NW, Di Menna ME, Cole ALJ, Skipp RA. 1996 - Characterisation of Thozetella tocklaiensis isolated from the roots of three grass species in Waikato pastures. New Zealand Journal of Botany 34, 517-522.

White TJ, Bruns T, Lee S, Taylor JW. 1990 - Amplification and direct sequencing of fungal ribosomal RNA genes for phylogenetics. PCR Protocols: a guide to methods and applications $18,315-322$. 